\title{
Effect of Initial pH, Chemical Preservatives and Storage Temperature on the Shelf-life of $\beta$-Carotene Rich Sweet Potato Dahi
}

\author{
Venkatraman Bansode ${ }^{1 *}$, Shovna Smruti ${ }^{2}$, Vijay Bahadur Singh Chauhan ${ }^{1}$, Sudhansu \\ Shekhar Mahanand ${ }^{3}$ and Archana Mukherjee ${ }^{4}$
}

\author{
${ }^{1}$ ICAR-Central Tuber Crops Research Institute, Regional Centre, Bhubneswar-751019 \\ Odisha, India \\ ${ }^{2}$ Utkal University, Vani Vihar, Bhubaneswar-751004, Odisha, India \\ ${ }^{3}$ College of Fisheries, CAU, Lembucherra-799210 Tripura, India \\ ${ }^{4}$ ICAR-Central Tuber Crops Research Institute, Trivandrum-695017, Kerala, India
}

*Corresponding author

\section{A B S T R A C T}

\begin{tabular}{|l|}
\hline Ke y w o r d s \\
$\begin{array}{l}\beta \text {-carotene, Dahi, } \\
\text { Initial } \mathrm{pH}, \\
\text { Microbiological } \\
\text { quality, } \\
\text { Preservative, Shelf- } \\
\text { life }\end{array}$ \\
\hline Article Info \\
\hline $\begin{array}{l}\text { Accepted: } \\
\text { 08 July } 2018 \\
\text { Available Online: } \\
\text { 10 August } 2018\end{array}$ \\
\hline
\end{tabular}

\section{Introduction}

Sweet potato (Ipomoea batatas L. Lam) belongs to the family convolvulaceae is a prime tuberous root crop. It has enormous future in food, feed but basically used for production of starch, flour, glucose and alcohol. They are most widely cultivated in tropical and warm temperate regions of the world. In India, it is $3^{\text {rd }}$ most essential tuber
A technique was developed for the production of $\beta$-carotene rich dahi from milk and freshly extracted sweet potato juice by inoculating with starter culture at $2 \%$ and incubated for different periods of time to yield dahi of $4.0 \pm 1,4.2 \pm 1$ initial $\mathrm{pH}$ and stored at two different temperature $4{ }^{\circ} \mathrm{C}$ and $30^{\circ} \mathrm{C}$ for 11 and 3 days. The sodium benzoate and potassium sorbate as preservatives were used and stored at $4^{\circ} \mathrm{C}$ and $30^{\circ} \mathrm{C}$. Quality Evaluation such as microbiological quality, $\mathrm{pH}$, titrable acidity, and sensory evaluation were done for checking the shelf-life of the samples. Analysing quality evaluation of sweet potato dahi with $0.05 \%$ concentration of potassium sorbate as preservative at $4^{\circ} \mathrm{C}$ considered acceptable with a shelf life of 37 days. The final $\beta$-carotene content of the acceptable dahi was found to be $6.4 \mathrm{mg} / 100 \mathrm{ml}$ and it is above the recommended level suggested by USDA. 
a vital role in combating the food shortages and malnutrition that may increasingly occur as a result of population growth and pressure on land utilization (Naskar et al., 2008).

Orange fleshed sweet potato is one of the cheapest sources of $\beta$-carotene. Vitamin $A$ is build-up by the human body when it has adequate amount of its precursor $\beta$-carotene. Vitamin A deficiency is a public health problem in more than half of all countries, especially in Africa and South-East Asia hitting hardest young children and pregnant women in low income countries. Vitamin A is an essential nutrient required for maintaining immune function, eye health, vision, growth and survival in human beings (WHO, 2009).

The high tuber yield coupled with high $\beta$ carotene content in orange flesh genotype $S T$ 14 (now released as Bhu-sona variety) indicates immense agricultural importance towards food and nutritional security especially in the fragile and food security coastal zones (Mukherjee and Naskar, 2012). Some of the orange flesh sweet potato varieties available in India are Kamala Sundari, Bhu-sona, Gouri, Sree Kanaka, etc. The Bhu-sona variety contains $\beta$-carotene of $13.83 \mathrm{mg} / 100 \mathrm{~g}$ in fresh root (Vimala et al., 2006).

Dahi (Indian yogurt) is a fermented dairy product of considerable importance in Indian subcontinent obtained by lactic acid fermentation of milk caused by single or mixed strains of lactic acid bacteria. There are different forms of dahi such as sweet dahi, sour dahi and flavoured dahi which are customarily consumed by the people of all over the world. Consumption of dahi is linked with several health benefits because of their presence of lactic acid bacteria. A wide range of health benefits, including improved lactose digestion, diarrhoea prevention, immune system regulation and lowering serum cholesterol level, have been described to ferment milk consumption (Chowdhury et al., 2011). With this increasing population, national and international diplomacy is extremely disturbed by food insufficiency and surpluses. So, there is always a need to preserve food for use during times of paucity. Preservatives are the substances that are capable of inhibiting the growth of microorganisms and masking the evidence of any such deterioration. Hence, the present work was conducted to overcome the vitamin A deficiency and nutritional enrichment of dahi by extending the shelf life with addition of preservatives and different storage temperatures.

\section{Materials and Methods}

\section{Collection of samples}

The freshly harvested sweet potato tubers were collected from the experimental farm of the Regional Centre of Central Tuber Crop Research Institute, Bhubaneswar, Odisha.

\section{Starter culture}

Half litre of cow milk (Source: Orissa Milk Federation, OMFED, Orissa) was taken and pasteurized at $80-90^{\circ} \mathrm{C}$ for about $10-15$ minutes. Then it was cooled at room temperature, $30 \pm 2{ }^{\circ} \mathrm{C}$. After cooling, $5 \mathrm{ml}$ of previously prepared homemade curd was inoculated into the milk. The whole mixture was kept in an incubator at $30^{\circ} \mathrm{C}$ for $12 \mathrm{~h}$ to prepare curd starter culture.

\section{Preparation of orange fleshed sweet potato juice}

$200 \mathrm{gm}$ of the orange fleshed sweet potato variety was weighed and washed properly to ward off the dirt. Then it was peeled off and was cut into cubes. Then the cubes were boiled for 15 minutes till they become tender. 
Then the whole mixture was allowed to cool down. After cooling, it was transferred into a grinder to make juice out of it. For each $200 \mathrm{gm}$ of sample, $200 \mathrm{ml}$ of water was used into order to make juice. After that, the juice was filtered using a muslin cloth and the extracted juice was used further in the experiment.

\section{Preparation of $\beta$-carotene rich sweet potato dahi}

Seven dahi samples were prepared with $10 \%$, $20 \%, 30 \%, 40 \%, 50 \%, 60 \%$, and $70 \%$ sweet potato juice concentration. $40 \%$ orange fleshed sweet potato juice incorporated dahi had the best consistency and texture and three replicates were maintained per treatment. Thus we used this sample for further experiment.

$40 \%$ of sweet potato juice was added in to previously boiled milk and were properly mixed. The samples were inoculated individually with $2 \%$ starter culture (Atker et al., 2010). All samples were incubated at $32^{\circ} \mathrm{C}$ for 24 hours to set the dahi.

\section{Setting of different initial pH}

The two different initial $\mathrm{pH}$ (4.0 and 4.1) were set by checking their $\mathrm{pH}$ with the help of $\mathrm{pH}$ meter at different intervals after the dahi is set. The samples were made in triplicates; each sample with specific $\mathrm{pH}$ value was kept at two temperatures i.e., $4^{\circ} \mathrm{C}$ and $30^{\circ} \mathrm{C}$.

\section{Addition of chemical preservatives}

Chemical preservatives were added to the samples in two different concentrations $0.1 \%$ and $0.05 \%$. The preservatives were weighed and mixed with the sample prior to incubation. After 24 hours of incubation at $32^{\circ} \mathrm{C}$ they were kept at $4^{\circ} \mathrm{C}$ and $30^{\circ} \mathrm{C}$ in triplicates to check their shelf life

\section{Microbiological analysis}

Microbiological quality assessments of the samples were done by determining the total coliform count and total fungal count. Microbial load of $\beta$-carotene rich sweet potato dahi was done by serial dilution and spread plate method.

\section{Chemical analysis}

The $\mathrm{pH}$ of prepared dahi was measured by using Digital $\mathrm{pH}$ meter (Global model DPH 500). The acidity was determined as per the method described in ISI part XI (1981).

\section{$\beta$-carotene estimation}

\section{Standard preparation of $\beta$-carotene}

Standard of $\beta$-carotene (1g enclosed in vial) was obtained from Hi-media laboratories. Stock solution of $\beta$-carotene was prepared by taking $10 \mathrm{mg}$ in $100 \mathrm{ml} \mathrm{n}$-hexane. The stock solution was diluted to different known concentrations e.g., 10, 20, 30 $\mu \mathrm{g}$, dilutions were obtained in $5 \mathrm{ml}$ of each n-hexane solutions. A standard curve was obtained by analysing its absorbance at $461 \mathrm{~nm}$ in UVVisible spectrophotometer.

\section{Pigment extraction}

$\beta$-carotene was extracted from the sample by the method of Khalil and Varananis, (1996) with slight modification. $20 \mathrm{ml}$ of the sample was homogenized in $50 \mathrm{ml}$ of acetone and then $0.1 \%$ (BHT) solution in acetone was added as an antioxidant. The resulting extract was filtered through Buchner's funnel. The residue was washed 5 times with acetone till it becomes colourless. The residue was discarded and the filtrate was combines with $30 \mathrm{gm}$ of anhydrous sodium sulphate. The anhydrous sodium sulphate was removed through filtration. The $\beta$-carotene content from 
the extracted pigment was determined by obtaining its absorbance at $461 \mathrm{~nm}$ wavelength in a UV-Visible spectrophotometer and correlating it with standard curve values.

\section{Sensory evaluation}

The prepared $\beta$-carotene rich sweet potato dahi was subjected for sensory evaluation. Ten individuals served as panellists, were trained to evaluate dahi as per score card (Scale 1-5) developed by committee of American Dairy Science Association (USDA, 1984) to evaluate dairy product for flavour, texture, colour and acceptability (Bodyfelt et.al.,1988).

\section{Results and Discussion}

\section{Changes in pH and acidity}

The $\mathrm{pH}$ and acidity values of different samples are shown in Table 1, 2 and 3. The average $\mathrm{pH}$ value was highest in sample treated with $0.1 \%$ of sodium benzoate at $4^{\circ} \mathrm{C}$ i.e., $4.12 \pm 0.08$, while $\mathrm{pH}$ was lowest in sample treated with $0.1 \%$ of potassium sorbate at $30^{\circ} \mathrm{C}$ i.e., $3.72 \pm 0.55$. There was a visible difference between the $\mathrm{pH}$ and acidity of control samples in comparison with the treated samples which contained sweet potato juice. The acidity of control samples were less than that of the experiment samples. This variation in $\mathrm{pH}$ may be due to various factors like incubation time, temperature, and amount of starter culture added. The difference in $\mathrm{pH}$ and acidity between control samples and experiment samples may be mainly due to addition of sweet potato juice. This result of dahi samples agrees with the findings of Desai et al., (1994) who found that acidity of the fruit dahi increased significantly due to addition of fruit pulp. The present result of the experiment also agrees with the findings of Mustafa (1997) who recorded that $\mathrm{pH}$ of dahi decreased after addition of fruit juice. The $\mathrm{pH}$ and acidity of control samples that does not contained sweet potato juice were $4.20 \pm 0.05$ and $1.36 \pm 0.10$ respectively while that of different samples containing sweet potato juice was found to have decreased $\mathrm{pH}$ and increased acidity. The $\mathrm{pH}$ of dahi that contained sweet potato juice ranged from $4.12 \pm 0.08$ to $3.72 \pm 0.55$. There was a gradual decrease in $\mathrm{pH}$ value and an increase in acidity with increasing storage days, but the changes were not so significant. However, the gradual decrease in $\mathrm{pH}$ because traditionally milk curd was influenced by fermentation condition (Seckinkomal, 2004). The $\mathrm{pH}$ and acidity values showed an inverse relation which is in line with the findings of Vahedi et al., (2008).

\section{Effect of temperature and initial pH}

Initial $\mathrm{pH}$ does not have any significant role in increasing the shelf-life of the samples. The shelf-life of samples set with initial $\mathrm{pH}$ was 11 days while that of control samples were 13 days. At $4^{\circ} \mathrm{C}$ samples set with initial $\mathrm{pH}$ had a shelf-life of 11 days, while at $30^{\circ} \mathrm{C}$ shelf-life was only 3 days.

\section{Effect of temperature and preservatives}

The $\mathrm{pH}$ values of the experiment sample with different concentrations of preservatives had a very little variation in their $\mathrm{pH}$ along the storage duration. This may be due to the antimicrobial activity of preservatives, which slowed down the growth of fermentation enhancing microbes. Hence, addition of preservatives increased the shelf-life of the product and kept the acidity level to an almost constant. Sample with $0.05 \%$ potassium sorbate at $4{ }^{\circ} \mathrm{C}$ had highest shelf-life of 37 days while $0.05 \%$ sodium benzoate had lowest shelf-life of 29 days at $4^{0} \mathrm{C}$.

At $30^{\circ} \mathrm{C}$ the samples became acidic within 5 days while at $4^{\circ} \mathrm{C}$ the shelf-life was significantly extended. At $30^{\circ} \mathrm{C}$ potassium sorbate was more effective in increasing the 
shelf-life than sodium benzoate. It was observed that all the samples kept in $4^{\circ} \mathrm{C}$ storage with preservatives at different concentrations maintained their color, odor, and taste for the first 25 days, and thereafter, few samples immediately changed their qualities.

\section{Total Coliform Count (TCC)}

Coliform count is an indication of hygienity of dahi preparation. Substantial number of E.coli in food suggests a general lack of cleanliness in handling and improper storage.

Table.1 Effect of initial $\mathrm{pH}$ and storage temperature on $\beta$-carotene rich Sweet potato dahi

\begin{tabular}{|c|c|c|c|c|c|c|}
\hline Temperature & $\begin{array}{c}\text { Initial } \\
\mathrm{pH}\end{array}$ & $\begin{array}{c}\text { No. of } \\
\text { Days }\end{array}$ & $\mathrm{pH}$ & $\begin{array}{l}\text { Acidity } \\
\text { (\% LA) }\end{array}$ & $\begin{array}{c}\text { TCC } \\
(\mathrm{Cfu} / \mathrm{g})\left(10^{1}\right)\end{array}$ & $\begin{array}{c}\text { TFC } \\
(\mathrm{Cfu} / \mathrm{g})\left(10^{3}\right)\end{array}$ \\
\hline \multirow[t]{7}{*}{$4^{\circ} \mathrm{C}$} & Control & 1 & 4.30 & 1.22 & 0 & 3 \\
\hline & & 3 & 4.27 & 1.23 & 0 & 3 \\
\hline & & 5 & 4.25 & 1.32 & 0 & 5 \\
\hline & & 7 & 4.19 & 1.41 & 1 & 7 \\
\hline & & 9 & 4.17 & 1.44 & 1 & 7 \\
\hline & & 11 & 4.18 & 1.45 & 2 & 5 \\
\hline & & 13 & 4.16 & 1.46 & 3 & 5 \\
\hline \multirow[t]{7}{*}{ Mean \pm SD } & & & $4.20 \pm 0.05$ & $1.36 \pm 0.10$ & $1 \pm 1.15$ & $5 \pm 1.63$ \\
\hline & 4.2 & 1 & 4.10 & 1.58 & 0 & 4 \\
\hline & & 3 & 4.10 & 1.55 & 0 & 5 \\
\hline & & 5 & 4.09 & 1.60 & 0 & 7 \\
\hline & & 7 & 3.98 & 1.62 & 2 & 10 \\
\hline & & 9 & 3.90 & 1.66 & 2 & 12 \\
\hline & & 11 & 3.90 & 1.60 & 3 & 14 \\
\hline \multirow[t]{6}{*}{ Mean \pm SD } & & & $4.01 \pm 0.09$ & $1.60 \pm 0.03$ & $1.16 \pm 1.32$ & $8.66 \pm 3.98$ \\
\hline & 4.0 & 1 & 4.10 & 1.55 & 0 & 3 \\
\hline & & 3 & 4.13 & 1.56 & 1 & 5 \\
\hline & & 5 & 4.00 & 1.49 & 2 & 4 \\
\hline & & 7 & 4.03 & 1.52 & 3 & 9 \\
\hline & & 9 & 4.06 & 1.58 & 3 & 8 \\
\hline Mean \pm SD & & & $4.06 \pm 0.05$ & $1.54 \pm 0.03$ & $1.8 \pm 1.30$ & $5.8 \pm 2.58$ \\
\hline \multirow[t]{2}{*}{$30^{\circ} \mathrm{C}$} & Control & 1 & 3.9 & 1.20 & 0 & 3 \\
\hline & & 3 & 3.8 & 1.34 & 0 & 4 \\
\hline \multirow[t]{3}{*}{ Mean \pm SD } & & & $3.85 \pm 0.07$ & $1.27 \pm 0.09$ & $\mathbf{0}$ & $3.5 \pm 0.70$ \\
\hline & 4.2 & 1 & 3.9 & 1.52 & 0 & 1 \\
\hline & & 3 & 3.9 & 1.54 & 1 & 3 \\
\hline \multirow[t]{3}{*}{ Mean \pm SD } & & & $3.9 \pm 0$ & $1.53 \pm 0.01$ & $0.5 \pm 0.70$ & $2 \pm 1.41$ \\
\hline & 4.0 & 1 & 4.1 & 1.65 & 0 & 6 \\
\hline & & 3 & 3.64 & 1.59 & 2 & 7 \\
\hline Mean \pm SD & & & $3.87+0.32$ & $1.62 \pm 0.04$ & $1 \pm 1.41$ & $6.5+0.70$ \\
\hline
\end{tabular}

Each value is average of three determinations 
Table.2 Effect of potassium sorbate and temperature on $\beta$-carotene rich Sweet potato dahi

\begin{tabular}{|c|c|c|c|c|c|c|c|}
\hline Preservative & Conc. & Temp. & $\begin{array}{l}\text { No. of } \\
\text { Days }\end{array}$ & $\begin{array}{l}\text { Acidity } \\
(\% \text { LA) }\end{array}$ & $\mathrm{pH}$ & $\begin{array}{c}\mathrm{TCC}(\mathrm{cfu} / \mathrm{g}) \\
\left(10^{1}\right)\end{array}$ & $\begin{array}{c}\text { TFC (Cfu/g) } \\
\left(10^{3}\right)\end{array}$ \\
\hline \multirow[t]{10}{*}{ Potassium sorbate } & $0.05 \%$ & $4^{\circ} \mathrm{C}$ & 1 & 1.50 & 4.22 & 0 & 0 \\
\hline & & & 5 & 1.50 & 4.20 & 0 & 1 \\
\hline & & & 9 & 1.52 & 4.12 & 0 & 3 \\
\hline & & & 13 & 1.53 & 4.11 & 0 & 3 \\
\hline & & & 17 & 1.55 & 4.02 & 0 & 3 \\
\hline & & & 21 & 1.55 & 4.01 & 0 & 4 \\
\hline & & & 25 & 1.60 & 4.01 & 0 & 4 \\
\hline & & & 29 & 1.60 & 4.00 & 0 & 6 \\
\hline & & & 33 & 1.62 & 4.00 & 2 & 6 \\
\hline & & & 37 & 1.62 & 4.00 & 1 & 7 \\
\hline \multirow[t]{4}{*}{ Mean \pm SD } & & & & $1.55 \pm 0.04$ & $4.06 \pm 0.08$ & $0.3 \pm 0.67$ & $3.7 \pm 2.21$ \\
\hline & & $30^{\circ} \mathrm{C}$ & 1 & 1.54 & 4.00 & 2 & 2 \\
\hline & & & 3 & 1.55 & 3.91 & 3 & 2 \\
\hline & & & 5 & 1.54 & 3.80 & 3 & 3 \\
\hline \multirow[t]{11}{*}{ Mean \pm SD } & & & & $1.54 \pm 0.00$ & $3.90 \pm 0.10$ & $2.66 \pm 0.57$ & $2.3 \pm 0.57$ \\
\hline & $0.1 \%$ & $4^{0} \mathrm{C}$ & 1 & 1.59 & 4.20 & 0 & 1 \\
\hline & & & 5 & 1.60 & 4.11 & 0 & 1 \\
\hline & & & 9 & 1.60 & 4.10 & 0 & 2 \\
\hline & & & 13 & 1.63 & 4.10 & 0 & 3 \\
\hline & & & 17 & 1.63 & 4.08 & 0 & 4 \\
\hline & & & 21 & 1.62 & 4.05 & 0 & 4 \\
\hline & & & 25 & 1.62 & 4.00 & 3 & 4 \\
\hline & & & 29 & 1.63 & 4.00 & 4 & 5 \\
\hline & & & 33 & 1.64 & 3.96 & 6 & 5 \\
\hline & & & 37 & 1.63 & 3.90 & 6 & 5 \\
\hline \multirow[t]{4}{*}{ Mean \pm SD } & & & & $1.16 \pm 0.08$ & $4.05 \pm 0.08$ & $1.9 \pm 2.60$ & $3.4 \pm 1.57$ \\
\hline & & $30^{\circ} \mathrm{C}$ & 1 & 1.54 & 4.11 & 1 & 1 \\
\hline & & & 3 & 1.60 & 3.98 & 3 & 1 \\
\hline & & & 5 & 1.59 & 3.09 & 3 & 1 \\
\hline Mean \pm SD & & & & $1.57 \pm 0.03$ & $3.72 \pm 0.55$ & $2.3 \pm 1.15$ & $1 \pm 0$ \\
\hline
\end{tabular}

Each value is average of three determinations

Table.4 $\beta$-carotene contents of dahi

\begin{tabular}{|c|c|}
\hline Shelf life (no of days) & $\beta$-carotene $(\mathrm{mg} / 100 \mathrm{ml})$ \\
\hline $\mathbf{1}$ & $7 \pm 0.1$ \\
\hline $\mathbf{5}$ & $6.96 \pm 0.05$ \\
\hline $\mathbf{9}$ & $6.93 \pm 0.05$ \\
\hline $\mathbf{1 3}$ & $6.9 \pm 0.11$ \\
\hline $\mathbf{1 7}$ & $6.8 \pm 0.1$ \\
\hline $\mathbf{2 1}$ & $6.73 \pm 0.11$ \\
\hline $\mathbf{2 5}$ & $6.66 \pm 0.15$ \\
\hline $\mathbf{2 9}$ & $6.63 \pm 0.11$ \\
\hline $\mathbf{3 3}$ & $6.5 \pm 0.0 .05$ \\
\hline $\mathbf{3 7}$ & $6.4 \pm 0.01$ \\
\hline
\end{tabular}

Each value is average of three determinations 
Table.3 Effect of sodium benzoate and temperature on $\beta$-carotene rich sweet potato dahi

\begin{tabular}{|c|c|c|c|c|c|c|c|}
\hline Preservative & Conc. & Temp. & $\begin{array}{c}\text { No. of } \\
\text { Days }\end{array}$ & $\begin{array}{l}\text { Acidity } \\
\text { (\% LA) }\end{array}$ & $\mathrm{pH}$ & $\begin{array}{c}\text { TCC } \\
(\mathrm{cfu} / \mathrm{g}) \\
\left(10^{1}\right)\end{array}$ & $\begin{array}{c}\text { TFC } \\
(\mathrm{cfu} / \mathrm{g}) \\
\left(10^{3}\right)\end{array}$ \\
\hline \multirow[t]{8}{*}{ Sodium benzoate } & $0.05 \%$ & $4^{0} \mathrm{C}$ & 1 & 1.35 & 4.20 & 0 & 2 \\
\hline & & & 5 & 1.33 & 4.14 & 0 & 3 \\
\hline & & & 9 & 1.36 & 4.11 & 0 & 2 \\
\hline & & & 13 & 1.36 & 4.10 & 0 & 4 \\
\hline & & & 17 & 1.38 & 4.02 & 0 & 4 \\
\hline & & & 21 & 1.40 & 4.01 & 0 & 6 \\
\hline & & & 25 & 1.40 & 4.00 & 0 & 6 \\
\hline & & & 29 & 1.41 & 3.91 & 0 & 7 \\
\hline \multirow[t]{3}{*}{ Mean \pm SD } & & & & $1.37 \pm 0.02$ & $4.06 \pm 0.09$ & 0 & $4.25 \pm 1.90$ \\
\hline & & $30^{\circ} \mathrm{C}$ & 1 & 1.41 & 3.96 & 0 & 2 \\
\hline & & & 3 & 1.42 & 3.95 & 3 & 6 \\
\hline \multirow[t]{10}{*}{ Mean \pm SD } & & & & $1.41 \pm 0$ & $3.9 \pm 0$ & $1.5 \pm 2.12$ & $4 \pm 2.82$ \\
\hline & 0.1 & $4^{0} \mathrm{C}$ & 1 & 1.45 & 4.23 & 0 & 1 \\
\hline & & & 5 & 1.44 & 4.21 & 0 & 2 \\
\hline & & & 9 & 1.46 & 4.21 & 0 & 2 \\
\hline & & & 13 & 1.43 & 4.20 & 0 & 2 \\
\hline & & & 17 & 1.45 & 4.11 & 2 & 2 \\
\hline & & & 21 & 1.44 & 4.10 & 2 & 4 \\
\hline & & & 25 & 1.46 & 4.10 & 3 & 4 \\
\hline & & & 29 & 1.47 & 4.00 & 3 & 6 \\
\hline & & & 33 & 1.51 & 4.00 & 4 & 6 \\
\hline \multirow[t]{4}{*}{ Mean \pm SD } & & & & $1.45 \pm 0.02$ & $4.12 \pm 0.08$ & $1.55 \pm 1.38$ & $3.22 \pm 1.64$ \\
\hline & & $30^{\circ} \mathrm{C}$ & 1 & 1.42 & 4.01 & 0 & 1 \\
\hline & & & 3 & 1.48 & 3.90 & 2 & 1 \\
\hline & & & 5 & 1.49 & 3.90 & 5 & 3 \\
\hline Mean \pm SD & & & & $1.46 \pm 0.03$ & $3.93 \pm 0.06$ & $2.33 \pm 2.51$ & $1.66 \pm 1.15$ \\
\hline
\end{tabular}

Each value is average of three determinations

The average coliform count per $\mathrm{ml}$ of dahi samples are presented in Table 1,2 and 3. The coliform count at $30^{\circ} \mathrm{C}$ increases significantly during $5^{\text {th }}$ day due to increase in the microbial activity at high temperature. Thus both low temperature and preservatives has considerable effect in lowering the number of microbes and help in increasing the shelf-life of the samples. The coliform count ranged between $0-6 \mathrm{cfu} / \mathrm{g}$ in all the samples. Count of all samples remained in the acceptable range $(<20)$ and thus these dahi samples were considered as safe for consumption.

Total Fungal Count (TFC)

TFC of dahi samples gave an indication of the total number of fungus and moulds present in the dahi. The highest TFC was recorded in the sample with initial $\mathrm{pH} 4.2$ at $4^{\circ} \mathrm{C}$ i.e., $8.66 \pm 3.98$, while lowest count was found in sample preserved at $4^{\circ} \mathrm{C}$ with $0.1 \%$ of Sodium Benzoate i.e., 3.22 \pm 1.64 . The decrease in fungal count in samples preserved with preservatives may be due to the anti-microbial 
action of preservatives. Count of all the samples remained in the acceptable range and thus these dahi samples were considered safe for consumption

\section{$\beta$-carotene content}

The $\beta$-carotene content of the developed dahi was estimated to be $7 \mathrm{mg} / 100 \mathrm{ml}$.The gradual reduction in the $\beta$-carotene content was depicted in Table 4. The $\beta$-carotene content after storage for 37 days the content was reduced to $6.4 \mathrm{mg} / 100 \mathrm{ml}$ of sample. However the final $\beta$-carotene content was less than the initial i.e., there was a decrease in $\beta$-carotene content during storage. This result is in accordance with Benard et al., (2013), which suggests that even after fermentation there is $93.97 \%$ retention of $\beta$-carotene content. The U.S. Department of Agriculture (USDA); recommend a dietary intake of $3-6 \mathrm{mg} \beta$ carotene/day which is associated with a lower risk of chronic disease, thus the developed product provides sufficient amount of $\beta$ carotene that can be very helpful in eradication of vitamin A deficiency.

In conclusion, the present study was undertaken with the aim of developing dahi with enhanced level of $\beta$-carotene. $\beta$-carotene is the precursor of Vitamin A. The final $\beta$ carotene content of product was estimated to be $6.4 \mathrm{mg} / 100 \mathrm{ml}$ and it is above the recommended level suggested by U.S. Department of Agriculture (USDA) i.e., 3-6 mg $\beta$-carotene/days. From the observations, we have concluded that dahi preserved with $0.05 \%$ of potassium sorbate at $4^{\circ} \mathrm{C}$ has the highest shelf-life up to 37 days and potassium sorbate is a better preservative than sodium benzoate. Initial $\mathrm{pH}$ does not have any significant effect on shelf-life of the product. The low temperature has significant effect on increasing the storage period. There was no measure constraint in preparing $\beta$-carotene rich sweet potato dahi unlike bean curd or soya curd where maintaining uniform distribution of the legume is a serious constraint. Moreover, dahi is a regular component of daily diet of many people in Indian Sub-continent. Enriching dahi with $\beta$ carotene helps to eradicate the Vitamin A deficiency among the people.

\section{References}

Akter N, Nahar A, Islam MN and Al-Amin, Effects of different level of Starter culture and sugar on manufacturing characteristics of Misti Dahi (Sweet Yoghurt). J. Bangladesh Agril. Univ, 2010, 8(2): 245-252.

Benard O, Shitandi A, Mahungu S, Malinga J and Ogata B, Effects of Lactic Acid fermentation on the retention of $\beta$ carotene Content in Orange Fleshed Sweet Potatoes. International Journal of Food Studies, 2013, 54 (3): 13-33.

Bodyfelt, FW, Tobias $\mathrm{J}$ and Trout G, The sensory Evaluation of Dairy products. Van No Strand Reinhold Publishers, 1988, New York.

Chowdhury NA, Paramanik K and Zaman W, Study on the Quality Assessment of Curd (dahi), Locally Available in Bangladeshi Market. World Journal of Dairy and Food Science 2011, 6(1): 1520.

Desai SR, Toro VA and Joshi SV, 1994, Utilisation of different fruits in the manufacture of Yoghurt, Indian $J$. Dairy Sci. 47: 870-874.

Khalil IA and Varananis FR, Carotinoid extraction and analysis by reversed phase HPLC system. Sarhad J. Agric. 1996, 105 (67): 15-21.

Laxminarayana K, Promotion of Sweet potato for livelihood and nutritional security in coastal saline soils of Odisha. Technical bulletin-59 Sweet potato for livelihood and Nutritional Security in Coastal Saline Soils, 2013, p 21. 
Mukherjee A and Naskar SK, Performance of orange and purple fleshed sweet potato genotypes in coastal location of Odisha, Journal of Root Crops,2012, 38 (1): 2631.

Mustafa M, A Study on the preparation of Fruit Dahi (yoghurt), M.Sc. Thesis, Bangladesh Agricultural University, Mymensingh, 1997, Bangladesh.

Naskar SK, Mukherjee A, Nedunchezhiyan $\mathrm{M}$ and Rao KR, Evaluation of sweet potato cultivars for quality traits. In: New R and D Initiatives in Horticulture for Accelerated Growth and Prosperity, $3^{\text {rd }}$ Indian Horticultural Congress, 6-8 November 2008, held at Bhubaneswar, Orissa, India, Abstracts, pp. 340.

Seckinkomal, Nutritional value of strained yoghurt produced by traditional method. Ege University, Turkey, 2004, 59: 4143.

USDA, Composition of Foods: Vegetables and Vegetable Products Raw processed and prepared, 1984, Agricultural Hand book, U.S. Department of Agriculture, Washington, D.C.

WHO, Global prevalence of vitamin A in populations at risk 1995-2005,WHO global database on vitamin A deficiency,2009, Geneva, World Health organisation.

Vimala B, Thushara R, Nambisan B and Sreekumar J, Evaluation of orange fleshed sweet potatoes for high yield and carotene content. In: $14^{\text {th }}$ Triennial Symp. Int. Soc. Trop. Root Crops, 2026 November 2006, Central Tuber Crops Research Institute, Thiruvananthapuram, India, pp. 55.

Vahedi N, Tehrani NM and Shahidi F, Optimization of fruit yoghurt formulation and evaluating its quality during storage. America-Eurasian Journal of Agricultural and Environmental Science, 2008, 3:922927.

\section{How to cite this article:}

Venkatraman Bansode, Shovna Smruti, Vijay Bahadur Singh Chauhan, Sudhansu Shekhar Mahanand and Archana Mukherjee 2018. Effect of Initial pH, Chemical Preservatives and Storage Temperature on the Shelf-life of $\beta$-Carotene Rich Sweet Potato Dahi. Int.J.Curr.Microbiol.App.Sci. 7(08): 960-968. doi: https://doi.org/10.20546/ijcmas.2018.708.109 